\title{
Written in Silver: Protective Medallions from Inner Oman
}

\author{
James Redman
}

The souqs and tourist markets of Oman are today filled with remnants from the days not long past when the country used to be home to a highly skilled and thriving silversmithing industry. Now, the domestic market is gone and the artifacts that have been left behind - the jewelry, daggers, and other assorted accouterments-are all hawked in shops sold by weight as souvenirs and collectibles. It is among this hodgepodge of metallic curios that silver discs about the size of an adult's hand with texts etched into them are to be found. These inscribed medallions are known locally as kirsh kitab and they were made in the Omani towns of Nizwa, Bahla, and Rustaq until the closing decades of the twentieth century. ${ }^{1}$ Originally crafted to be worn around a woman's neck or placed near a bed, these pieces were thought to provide their owners with protective benefits ${ }^{2}$ by bearing words from the hallowed scriptural authority of the Qur'ān (fig. 10.1). ${ }^{3}$

However, the kirsh kitab must be separated from the kinds of generic charms meant to defend against a wide array of metaphysical onslaughts because they were explicitly created to combat the ravages of a specific jinniya, Umm al Subyan, the "Mother of Boys," so named for "her capacity of causing the death of infants." 4 For parents and children, Umm al Subyan has a frightening

1 A silver dealer interviewed by the author, Nizwa, Oman, December 1, 2016.

2 Ibrahim, interviewed by the author, Nizwa, Oman, September 2, 2017.

3 James Grehan, Twilight of the Saints: Everyday Religion in Ottoman Syria and Palestine (Oxford: Oxford University Press, 2016), 153-55.

4 Edward Alexander Westermarck, Ritual and Belief in Morocco (New Hyde Park, NY: University Books, 1968), 1: 400. reputation that reaches beyond Oman and stretches across the Arabian Peninsula ${ }^{5}$ to North Africa ${ }^{6}$ and through the Indian Ocean to Zanzibar. ${ }^{7}$ To give some impression of this "child-witch," 8 a portion of "The Seven Covenants of Solomon" taken from a Cairene amulet provides a harrowing portrait of the jinniya in all her dreadful glory:

"[I]t is related of the prophet of God, Solomon, son of David, (peace upon both) that he saw an old woman with hoary hair, blue eyes, joined eyebrows, with scrawny limbs, disheveled hair, a gaping mouth from which flames issued. She cleaved the air with her claws and broke trees with her loud voice. The prophet Solomon said to her, "Art thou of the jinn or human? I have never seen worse than you." She said, "O prophet of God, I am the mother of children (Um-es-Subyan). I have dominion upon the sons of Adam and daughters of Eve, and upon their possessions. I enter houses and gobble like turkeys and bark like dogs, and low like cows, and make a noise like camels, and neigh like horses, and bray like donkeys, and hiss like serpents, and represent everything. I make wombs barren and destroy children. I come to women and close their wombs and leave them, and they will not conceive, and then people say they are barren.

5 C. Snouck Hurgronje, Mekka in the Latter Part of the 19th Century: Daily Life, Customs and Learning. The Moslems of the East-Indian-Archipelago, trans. J.H. Monahan (London: Luzac, 1931), 99-100.

6 Westermarck, Ritual and Belief, 1: 400.

7 Lorenzo Declich, "Zanzibar: Some Nineteenth-Century Arabic Writings on Healing," in The Transmission of Learning in Islamic Africa, ed. Scott S. Reese (Leiden: Brill, 2004), 269 .

8 Samuel M. Zwemer, Arabia: The Cradle of Islam (New York: Fleming H. Revell, 1900), 283. 


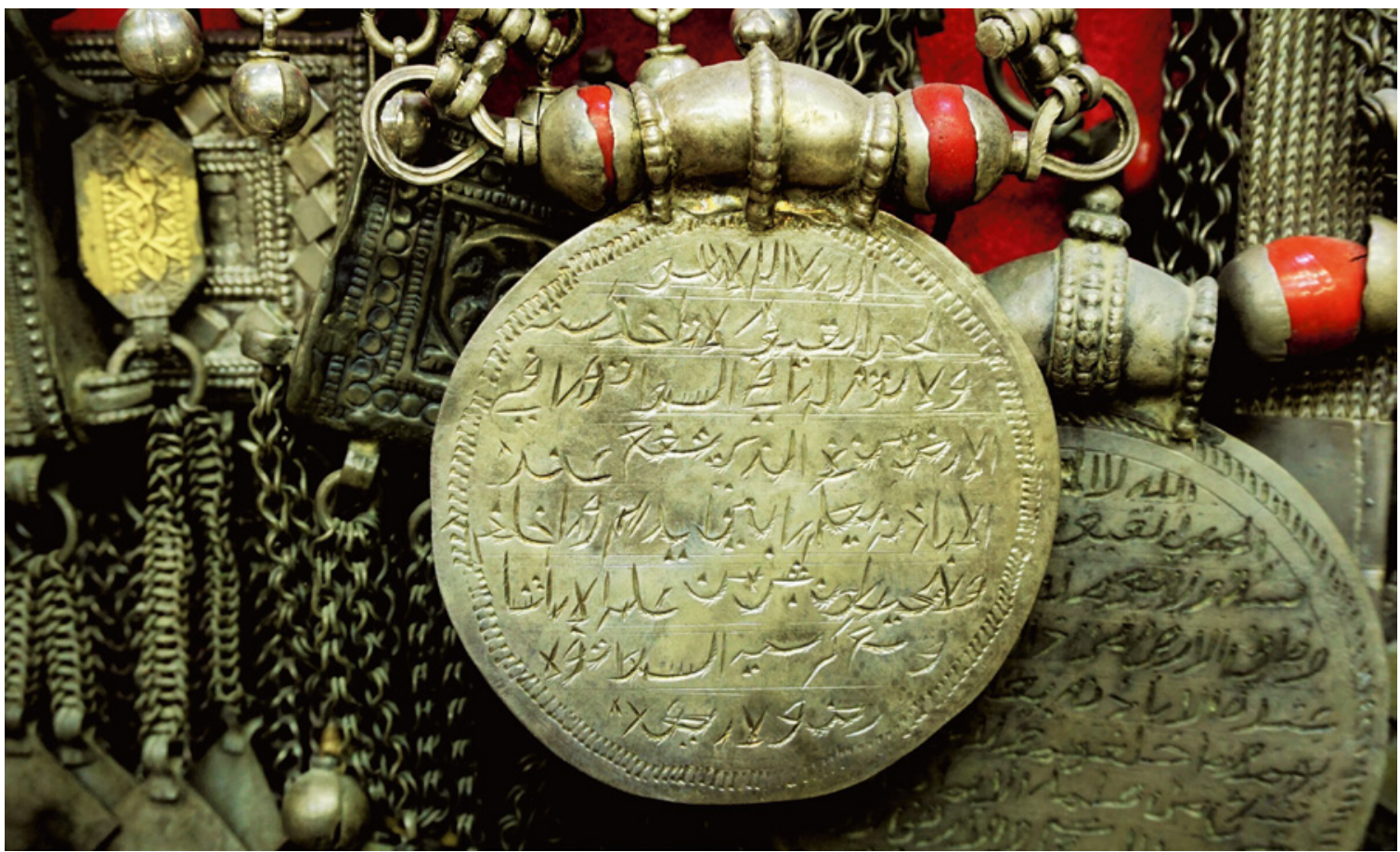

FIGURE 10.1 Several kirsh kitab hang on a wall among other bits and pieces of silverwork in a shop owned by a former sa'ig in Nizwa, Oman.

I come to a woman in pregnancy and destroy her offspring. It is I, O prophet of God, who come to the woman engaged and tie the tails of her garments, and announce woes and disasters. It is I, O prophet of God, who come to men and make them impotent... It is I, O prophet of God, who come to men and oppose their selling and buying. If they trade, they do not gain, and if they plow they will not reap. It is I, O prophet of God, who cause all these." 9

This is the titanic incarnation of calamities that women in inner Oman had to safeguard themselves against: a wicked presence whose cruelty

9 Samuel M. Zwemer, The Influence of Animism on Islam: An Account of Popular Superstitions (New York: Macmillan, 1920), 193-94. It is important to approach Zwemer's firsthand accounts about popular Islamic practices from a century ago with caution. Though a voracious collector of data, he also approached Islam and its adherents through could only be checked by a kirsh kitab silver medallion (fig. 10.2).

Flat, circular metal, though, was not the remedy for deflecting the havocs brought on by Umm al Subyan, even if it was the vessel. To work and to become a kirsh kitab, it needed the divine language of the Qur'ān, oftentimes accompanied by a scrawled image of a tied and bound Umm al Subyan herself, to actually incapacitate the jinniya and prevent her from filling her ghastly desires. This reliance on words recognizably makes the texts on the kirsh kitab a focal point and a vehicle for grasping how these pieces were "enmeshed in circumstance, time, place and society"10 when the

the lens of a Christian missionary. For further discussion, see Eleanor Abdella Doumato, Getting God's Ear: Women, Islam, and Healing in Saudi Arabia and the Gulf (New York: Columbia University Press, 200o), 43-58.

10 Edward W. Said, "The Text, the World, the Critic," The Bulletin of the Midwest Modern Language Association 8, no. 2 (1975): 4 . 


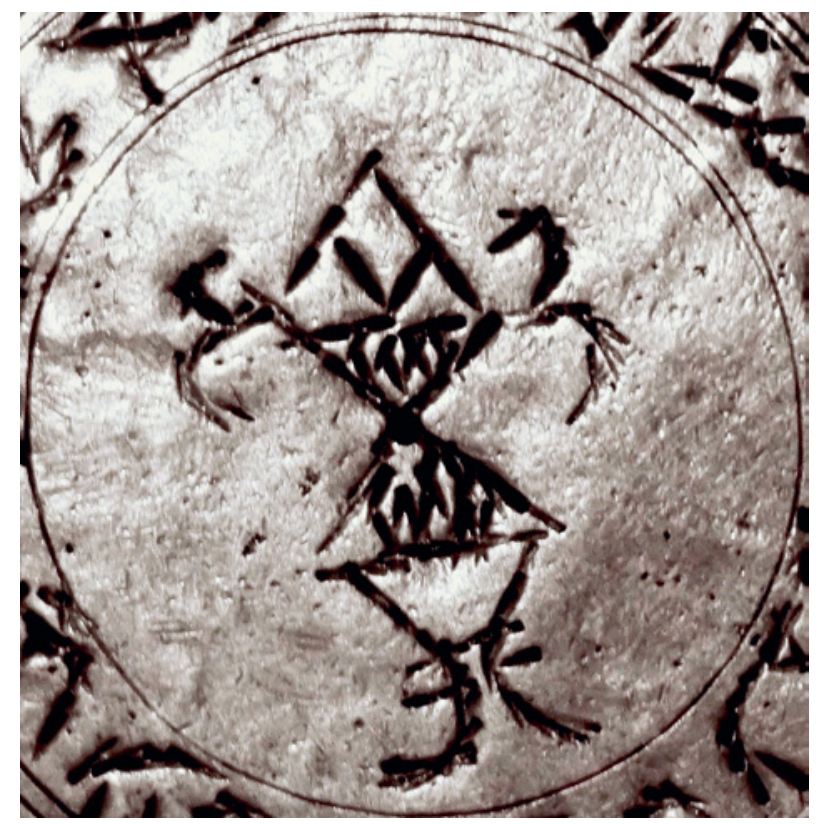

FIGURE 10.2

The horrid likeness of Umm al Subyan etched into the surface of a kirsh kitab. In this image, the desired effect of the kirsh kitab upon the jinniya is clear: her legs are depicted as being bound to signify that she is powerless against the owner of the kirsh kitab. This kirsh kitab variation also represents a double indemnity against Umm al Subyan's torments since she is visibly surrounded, or trapped, by the words of "Aya al Kursi." writings were surrogates for their makers' textual knowledge. This chapter examines what these texts say about the utility of that knowledge, especially for protection, when it is conveyed in a very imperfect form through incomplete and inexact scripts. Still, these texts are inseparable from the legacy of Oman's silver trade, and understanding this market is indispensable for building a framework for the words that were scored within its quarters.

\section{A Brief Overview of the Silver Craft Industry in Oman}

The story of Oman's silver craft industry is vital for any appraisal of the kirsh kitab for several reasons, but foremost because these protective medallions had to first be fabricated from silver before anything else could be done with them. In the Omani interior towns where these pieces come from, the silver discs, hangers, and chains, not to mention any trimmings like gold leaf or red beads, would each have to be crafted and then assembled by a sa'ig (pl. suwwag), a silversmith, who would give every kirsh kitab its form. Thereafter, the amulets would be sold in a silversmith's workshop alongside necklaces, bracelets, rings, and other silver wares. ${ }^{11}$ Plainly, from manufacture to market, the kirsh kitab have for some time been a regular part of the Omani silver trade.

While shrouded in speculation, the appearance of silversmithing in Oman is variously dated to the late eighteenth ${ }^{12}$ and the mid-nineteenth ${ }^{13}$ centuries, although the conclusion that it "has been going on for as long as anyone can remember"14 is likely just as accurate. Certainly, there is some data that might allow for guesswork, like the arrival in Muscat of Jewish silversmiths from Iraq in the 1830 , or a Western visitor to Oman in 1845 noting

\footnotetext{
11 Daud, interviewed by the author, Nizwa, Oman, December 1, 2016.

12 Jehan S. Rajab, Silver Jewellery of Oman (Kuwait City: Tareq Rajab Museum, 1997), 31.

13 Aude Mongiatti, Fahmida Suleman, and Nigel Meeks, "Beauty and Belief: The Endangered Tradition of Omani Silver Jewellery," The British Museum Technical Research Bulletin 5 (2011): 1.

14 Ruth Hawley, "Omani Silver," Proceedings of the Seminar for Arabian Studies 6 (1976): 8.
} 
the "dollars pendant" worn by the women. ${ }^{15}$ The surviving silver jewelry and accessories of Sayyida Salme bint Sa'id, the daughter of Sayyid Sa'id bin Sultan, Imam of Muscat and Sultan of Zanzibar (r. 1804-1856), ${ }^{16}$ also provide a solitary glimpse into what royal regalia looked like on Oman's distant East African shores in the 1860 os $^{17}$ But, as these samples show, the information is simply too erratic and anecdotal to allow for a satisfying chronological sketch of Oman's silver heritage to be formulated.

With this degree of uncertainty about when Omani silverwork started being produced, a similar lack of clarity can be expected for its stylistic and design roots. Given coastal Oman's extensive history of long distance trade that stretches back over a thousand years, spanning from China and India through the Arabian Gulf and all the way to Africa, ${ }^{18}$ it is difficult to imagine that the craftsmanship of Omani silver artisans would remain immune to the influences of such a regional emporium. ${ }^{19}$ Indicative of one direction of this flow is Jehan Rajab's observation that, when Oman ruled Zanzibar, "Zanzibari jewellery was almost indistinguishable from that found in Oman and no doubt many silversmiths must have gone with their families to East Africa and remained there." ${ }^{20}$ Unfortunately, what is missing from this statement is an acknowledgement of the interactions between Omani and African aesthetics in Zanzibar, or the very real possibility that inspirations from

15 Luitgard Mols, "Art in Silver. Traditional Jewellery from Oman," in Oman, ed. Luitgard Mols and Birgit Boelens (Amsterdam: Production Foundation De Nieuwe Kerk and Hermitage Amsterdam, 2009), 131 and 134, respectively. Percy Cox, foreword to Said bin Sultan (1791-1856). Ruler of Oman and Zanzibar, by Rudolph Said-Ruete (London: Alexander-Ouseley, 1929), ix-xi. Mongiatti, Suleman, and Meeks, "Beauty and Belief," 2.

18 Uzi Rabi, "The Ibadhi Imamate of Muhammad Bin "Abdallah al-Khalili (1920-54): The Last Chapter of a Lost and Forgotten Legacy," Middle Eastern Studies 44, no. 2 (2008): 170.

19 Mols, "Art in Silver," 133.

20 Rajab, Silver Jewellery, 55-57.
East Africa streamed back to Oman. When the island's Indian silver merchants ${ }^{21}$ are added to this mix, even the labels of Omani or Zanzibari jewelry are probably too restrictive. Turning to Oman proper, the land served not only as a point for cargoes along the trade routes but also as a stopover for populations on the move, with this traffic amplified on the coasts and reduced considerably in the interior. ${ }^{22}$ So, in addition to the aforementioned Iraqi Jewish silversmiths in Muscat by the $1830{ }^{23}$ it is also presumed that Yemeni Jewish silversmiths helped shape Omani jewellery patterns ${ }^{24}$ along with Pakistani Baluchis. ${ }^{25}$ Of course, this international milieu of circulating goods and peoples is a woefully incomplete portrayal of Omani silver design; local choices, tastes, and sensibilities about what is desirable and fashionable must also be taken into account. ${ }^{26}$ The key is to recognize that these local preferences have long coexisted with the same cycles of geographic mobility and mercantile networks that have defined the Omani experience over the past centuries.

In sharp contrast to the knowledge void that clouds our current understanding about the origins of Oman's silver heritage, there are better insights into what this jewelry has meant for its owners. As Richardson and Dorr summarize, "[s]ilver jewellery is traditionally given to a woman in the form of a dowry at the time of her marriage, and is deemed her personal property, to be exchanged at her discretion for goods and currency in times of

\footnotetext{
21 Mols, "Art in Silver," 135.

22 Uzi Rabi, The Emergence of States in a Tribal Society: Oman Under Sa'id bin Taymur, 1932-1970 (Brighton: Sussex Academic Press, 2011), 5 .

23 Mols, "Art in Silver," 134.

24 Ruth Hawley, Omani Silver (London: Longman, 1984).

The Lancasters also recorded the presence of traveling Iranian Baluchi silversmiths in neighboring Ras alKhaimah prior to oil and it is hard to think that their circuits never touched Omani soil. For details, see William Lancaster and Felicity Lancaster, Honour Is in Contentment: Life Before Oil in Ras al-Khaimah (U.A.E.) and Some Neighboring Regions (Berlin: Walter de Gruyter, 2011), 259-61. 
need. Jewellery represents security and portable wealth and as such ... is ultimately viewed as a liquid asset."27 But silver jewelry was not just a liquid asset; it was literally a plastic asset that could easily be transformed into capital by shaving away its pieces, melting it down partially or entirely, or fabricating it into a different thing altogether. ${ }^{28}$ On the other hand, the benefits of liquidity and plasticity may have been slightly offset by the fact that silver jewelry was not an economically productive asset; it was a form of insurance reserved for tough times. ${ }^{29}$

Then again, the economic value of silver objects should not overshadow their significance as personal adornments and their ability to act as visual indicators of their wearers' social and marital standing, or as markers of their regional and tribal identities. ${ }^{30}$ Another part of the metal's allure, which could be aided by being worked into something wearable, was its supposed curative and protective merits that were thought to be capable of both healing physical ailments and providing amuletic safety against unseen malevolence. Some authors have assigned this penchant for silver to the Prophet Muhammad's dislike of gold jewelry. ${ }^{31}$ However, Sayyida Salme bint Sa'id's memoirs of Omani life in nineteenth-century Zanzibar make this assertion debatable, since she witnessed that, for their own protection, "the higher classes take sayings from the Koran engraved on gold or silver medals, suspended from the neck by a chain."32 For most Omanis, gold was prohibitively expensive and local custom held that it was only silver, and not gold, that had the inherent ability to

27 Neil Richardson and Marcia Dorr, The Craft Heritage of Oman (Dubai: Motivate Publishing, 2003), 1:166.

28 Ibid.

29 William C. Young, The Rashaayda Bedouin: Arab Pastoralists of Eastern Sudan (Belmont, CA: Wadsworth, 2002), 62-63. Mongiatti, Suleman, and Meeks, "Beauty and Belief," 2-3.

31 Mols, "Art in Silver," 135-37.

32 Qtd. in Emily Ruete, Memoirs of an Arabian Princess, trans. Lionel Strachey (New York: Doubleday, Page, 1907), 68. defend its wearers against bad luck and unearthly tribulations. ${ }^{33}$

By the last quarter of the twentieth century, the heydays of Omani silverwork had passed and Omani silversmithing was on the verge of extinction due to a confluence of pressures, some of which were symptomatic of the challenges faced by all Omani craft industries during this period and others that were particular to the silver industry itself. Primarily, the bulk of this marketplace collapse should be viewed as part of the broader changes that were already shaking Oman: the 1970 coup d'etat and the new government's policies of "awakening" the country with massive infrastructural, economic, and bureaucratic developments. ${ }^{34}$ For handicraft producers, this had many consequences. For instance, the state's investments in the private and public sectors created salaried jobs that siphoned off the potential next generation of craftsmen, ${ }^{35}$ and the advent of a national education system ${ }^{36}$ undoubtedly weakened the father-to-son informal apprenticeships of many crafts. The burgeoning economy also increased the import of products that could compete with and replace locally manufactured items, ${ }^{37}$ meaning that outside competition was growing at precisely the same moment that domestic artisans were being steered to new higher paying occupations. ${ }^{38}$ Not surprisingly, almost overnight many handicraft industries were suddenly obsolete. ${ }^{39}$

Oman's silversmithing trade was battered by these trends and confronted with its own challenges as local tastes, funded by the growth in spending power, gradually replaced silver with

\footnotetext{
33 Rajab, Silver Jewellery, 34.

34 Mandana E. Limbert, In the Time of Oil: Piety, Memory, and Social Life in an Omani Town (Stanford: Stanford University Press, 2010), 5-6. Richardson and Dorr, The Craft Heritage of Oman, 2:518. Limbert, In the Time of Oil, 86. Richardson and Dorr, The Craft Heritage of Oman, 2:519. Avelyn Forster, Disappearing Treasures of Oman (Somerset: Archway Books, 1998), 25. Richardson and Dorr, The Craft Heritage of Oman, 2:512-13.
} 
gold. According to Mongiatti, Suleman, and Meeks, what began merely as a way to enhance silver by adding gold to it eventually turned into a fullblown desire for gold jewelry once it could be afforded:

"[T]he demand for the silversmith's craft has declined in recent years ... The addition of small elements of gilded decoration on Omani silver jewellery gained popularity from the 196os onwards, during a time when earnings increased and vast quantities of gold were readily available from Saudi Arabia and Dubai ... Over time, however, Omani's [sic] women's fondness for small gilded embellishments developed into a demand for pieces made entirely of gold. Indian goldsmiths have largely met this demand, having established a thriving trade in Oman and neighboring Dubai and, interestingly, traditional designs of Omani silver are sometimes reworked as entire gold pieces or smaller, lighter versions in gold." 40

The effect of this swing in precious metal choices was already noticeable by 1975 , only five years into the regime's rapid modernization plans, when Ruth Hawley found that, in the southern Dhofar region, "[w]ith the exception of the atngeel (a hair ornament) silver does not seem to be made up into jewellery any more, as gold has almost entirely replaced it." ${ }^{11}$ Thus, it comes as little wonder that silversmithing "all but died" 42 after several decades of its workforce shrinking and demand for its products dwindling. Today, many Omani silver dealers contract expatriate craftsmen, such as Pakistanis, to fill any orders they get for brand new "traditional" silver jewelry. ${ }^{43}$

To some extent, it can be anticipated that the fates of Oman's kirsh kitab rose and fell with its silver fortunes given that the former was, literally, part of the stock and trade of the latter. Like with

40 Mongiatti, Suleman, and Meeks, "Beauty and Belief," 1.

41 Hawley, "Omani Silver," 88.

42 Forster, Disappearing Treasures of Oman, 25.

43 Daud, interviewed by the author, Nizwa, Oman, December 1, 2016. silver craft industry overall, the circumstances surrounding the appearance of these amulets in inner Oman are probably lost to posterity, aside from vague notions that they are "ancient," which in the parlance of the souqs can mean from roughly one hundred years ago. ${ }^{44}$ Also, it seems that the production of kirsh kitab trailed off almost in conjunction with the loss of Oman's silver markets, with manufacturing ending in the $1980 \mathrm{~s}^{45}$ or 1990s. ${ }^{46}$ Some Omanis say that the kirsh kitab stopped being made because, as with silver goods in general, Omani leanings shifted to gold ${ }^{47}$ and away from the heavy, bulky silver medallions that could weigh over a quarter of a kilogram. ${ }^{48}$ Other Omanis, departing from this materialistic and market-centered approach and thinking in terms of religiosity, insist that the kirsh kitab fell from favor because they date from the days of the "old beliefs that were not right" and that sales dried up after "people learned how to believe correctly." 4 The more probable scenario is that all of these explanations contain some validity depending on the circumstances. Now, it is rumored that there are workshops in Oman where Pakistanis are using electric engravers to churn out any kirsh kitab that might be needed by retailers. ${ }^{50}$

\section{$2 \quad$ The Texts in the Silver}

Without question, there are multiple layers of meaning wrapped around the kirsh kitab Muhammad, interviewed by the author, Nizwa, Oman, May 10, 2018.

Khaled, interviewed by the author, Nizwa, Oman, May 10,2018

46 Said, interviewed by the author, Nizwa, Oman, December 2, 2016 .

47 A silver dealer interviewed by the author, Nizwa, Oman, December 1, 2016.

48 Khaled, interviewed by the author, Nizwa, Oman, May 10, 2018.

49 Muhammad, interviewed by the author, Nizwa, Oman, December 1, 2016.

50 Daud, interviewed by the author, Nizwa, Oman, December 1, 2016. 
individually and collectively. At any given moment, these medallions can variously be seen as commodities, personal adornments, transportable wealth, family mementoes, tourist souvenirs, and so forth. This incomplete list can also serve as a basis for studying most other pieces of old Omani silver jewelry, but the kirsh kitab have additional features that set them apart. Namely, they were believed to be endowed with the capacity to shield their owners from the misfortunes wrought by an otherworldly force, a capacity that largely depended on the application of Qur'anic texts. For this reason, the kirsh kitab probably communicate as much or more as documents, as textual products, than they do as anything else and it is this probability that is underpinning the present discussion.

Quite literally, a kirsh kitab does not exist without texts. Even the name kirsh kitab, or "coin writing," designates that it is the appliance of written text that makes a kirsh kitab what it is. Without text, it is not a kirsh kitab; it is either unfinished raw material or, if embellished on one side with gold leaf shaped in a sunburst design, a necklace known as a sumpt. Conversely, though, when a sumpt has texts engraved into its plain side, i.e., the side of the silver disc without gold decoration, it ceases to be called a sumpt and, instead, it is a kirsh kitab or kirsh kitab with gold (ma dhihab). ${ }^{51}$

Yet, a kirsh kitab is more than a silver slate used for the recording of texts and writing; as already mentioned, for it to have any protective potential, a kirsh kitab must have had words from the Qur'ān engraved into its surface. Almost exclusively, these words came from the "Aya al Kursi" ("The Throne Verse") of Surat al Baqarah (The Chapter of the Cow). ${ }^{52}$ This attribute, in and of itself, does not

$5^{1}$ Khalid, interviewed by the author, Nizwa, Oman, May 10, 2018.

52 The author documented 116 kirsh kitab samples in Oman. Of this number, 106 ( $91 \%$ ) used words from the "Aya al Kursi" exclusively, and three combined words from the "Aya al Kursi" with those from another verse. In total, 109 (94\%) examples contained words from "Aya al Kursi." One kirsh kitab was engraved with words from Surat Ya Sin (Chapter Ya Sin) and two others with words from Surat al Fatihah (The Opening Chapter). make the kirsh kitab unique as there are many little silver "Aya al Kursi" pendants and lockets that are widely available nearly everywhere today. As textual products and as texts, the kirsh kitab bear little resemblance to the contemporary "Aya al Kursi" medals, but the distinctions between the two are useful for illustrative purposes. So, whereas the new stocks might fall into a category of products that are viewed as "the growing mass commoditization of the Islamic tradition,"53 the kirsh kitab were very much a local handicraft tradition, and this difference likely accounts for the disparities found in each of their texts. With the mass-marketed necklaces, the perfection and tiny text of the mechanized engraving of the "Aya al Kursi" is something akin to Walter Ong's commentary about printing books: "Printed texts look machine-made, as they are.... Typographic control typically impresses more by its tidiness and inevitability: the lines perfectly regular, all justified on the right side, everything coming out even visually, and without the aid of guidelines or ruled borders that often occur in manuscripts.... By and large, printed texts are far easier to read than manuscript texts." ${ }^{4}$ If today's "Aya al Kursi" pendant is analogous to the printed words described by Ong, then the kirsh kitab must surely embody his thoughts about manuscripts.

In fact, the manufacture of kirsh kitab can be aligned quite neatly with manuscript culture. To begin with, every piece is the antithesis of print-capitalism with its faculty for "infinite reproduction" stripped of "individualizing ... habits." ${ }^{\prime 5}$ Rather, what is seen with each kirsh kitab through its handwritten content is the epitome of

The four remaining kirsh kitab were each made up of a different patchwork of ayat from the Qurān and one of these also included a du'a (prayer). Gregory Starrett, "The Political Economy of Religious Commodities in Cairo," American Anthropologist 97, no. 1 (1995): 65 .

54 Walter J. Ong, Orality and Literacy: The Technologizing of the Word (New York: Routledge, 2002), 120.

55 Benedict Anderson, Imagined Communities: Reflections on the Origin and Spread of Nationalism (London: Verso, 2006), 44 . 
personalized predilections, as extra phrases, numbers, and symbols are blended with ayat (Qur'ān verses; sing. aya) that might also have missing, misspelled, or broken words. ${ }^{56}$ Granted, while this may appear to be an unpardonable level of ineptitude or an exhibit of charm writing by way of the occult scriptural sciences, ${ }^{57}$ and it is within the realm of possibilities that both or either of these prospects might be the case, it is also in line with the errors that typify manuscripts. ${ }^{58}$ Moreover, even in the medieval Arabic manuscript industry, with its highly trained copyists and rigorous proofing protocols, authors sometimes concluded their original tomes with apologies in anticipation of the inevitable mistakes that they expected to be introduced by others in later renditions. ${ }^{59}$ This begs the question that, if these inaccuracies were the norm for scribes and copyists who used conventional writing materials, should there be any expectation that the use of silversmithing tools on a resistant surface will yield higher levels of textual accuracy? Probably not, although it does make the irregular and inconsistent texts on the kirsh kitab even more understandable and emblematic of manuscript traditions.

Obviously, texts cannot create themselves and the kirsh kitab are no exception. Here, again, the manuscript model provides a guide to follow, this time for gathering insights into what it meant to produce the kirsh kitab as texts. Like with manuscripts, the kirsh kitab are "producer-oriented" texts in the sense that every single copy corresponds directly to an individual maker's time and

56 There are 1,258 total irregularities in the 116 kirsh kitab recorded by the author. These irregularities include words missing from the ayat, misspelled words, broken words, as well as added words, numbers, and symbols. Emilio Spadola, "Writing Cures: Religious and Communicative Authority in Late Modern Morocco," The Journal of North African Studies 14, no. 2 (2009): 155-6o.

$5^{8}$ Marshall G.S. Hodgson, The Venture of Islam (Chicago: University of Chicago Press, 1974), 2: 444.

59 Johannes Pedersen, The Arabic Book, trans. Geoffrey French (Princeton, NJ: Princeton University Press, 1984), 47-49. effort, unlike the automated reproduction of innumerable copies from a single prototype. ${ }^{60} \mathrm{Howev}-$ er, the producers of the kirsh kitab texts were not from the same mold as the manuscript copyists, scribes, notaries, or other document writers, ${ }^{61}$ who were known for their competencies with texts and writing, nor were they drawn from the ranks of the shuyukh or any other learned "carriers of the Quran,"62 who were commonly tasked with duplicating the scriptures for the laities. Instead, the kirsh kitab authors were silversmiths; the very same suwwag who crafted the silver discs and affixed them to chains also wrote the Qur'anic words by scratching them into being. ${ }^{63}$

To write a kirsh kitab, it is presumed that a sa'ig had to have a skill somewhat related to what Dale Eickelman identified as "mnemonic domination" or "mnemonic possession,"64 but in a more diluted guise, since neither the Qur'ān nor any other religious treatises were to be memorized in their entirety. ${ }^{65}$ What an adept craftsman who could make a kirsh kitab was thought to mnemonically hold, it turns out, was flawless, pristine memorization of the "Aya al Kursi,"66 coupled with the ability to write it. The use of patterns, templates, or even the Qur'ān as a guide to copy from was expressly ruled out; for the sacred texts on a kirsh kitab to have any effectiveness, they had to come straight from the

\footnotetext{
6o Ong, Orality and Literacy, 120.

61 Brinkley Messick, The Calligraphic State: Textual Domination and History in a Muslim Society (Berkeley: University of California Press, 1993), 224-26.

62 Dale F. Eickelman, Knowledge and Power in Morocco: The Education of a Twentieth-Century Notable (Princeton, NJ: Princeton University Press, 1985), 66-67, and 77 , respectively.

63 Salim, interviewed by the author, Nizwa, Oman, November 4, 2017.

64 Dale F. Eickelman, "The Art of Memory: Islamic Education and Its Social Reproduction," Comparative Studies in Society and History 20 (1978): 489 and 495, respectively.

65 Eickelman, Knowledge and Power, 50-59.

66 Ahmed, interviewed by the author, Nizwa, Oman, May 10, 2018.
} 
memory of the sa'ig who wrote it. ${ }^{67}$ It is not immediately clear why the memorization of the words was necessary. The Qur'ān, it must be remembered, is a "recitation-text" 68 which, at its foundation, "denies its writtenness while foregrounding its recitational quality,"69 and this might have fostered a popular, idealized conviction that its revered words were formerly produced solely from memorization and not by any other method. Furthermore, studies in other Muslim communities have found creeds that maintain that Qur'ānic words have to be "internalized ... in the head"70 before their strength and force can be fully realized, and it is plausible that this doctrine or something like it may have applied to inner Oman whenever the protective powers of texts were needed. But whether or not these are the reasons behind the importance of memorized texts for making the kirsh kitab is not as crucial as seeing that it was a sa'ig's encapsulation of the words he

"Aya al Kursi"

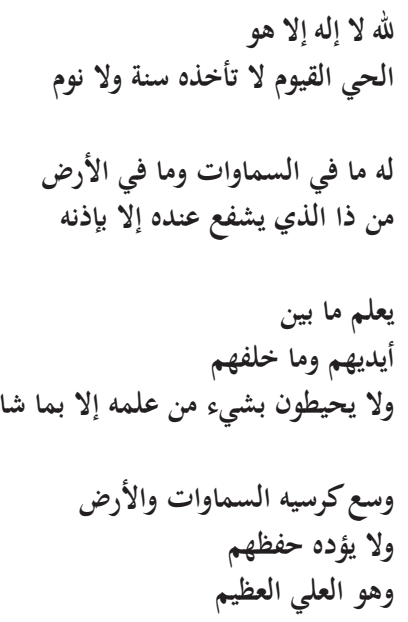

67 Salim, interviewed by the author, Nizwa, Oman, May 11, 2018.

Brinkley Messick, "Just Writing: Paradox and Political Economy in Yemeni Legal Documents," Cultural Anthropology 4, no. 1 (1989): 27.

69 Ibid., 28.

70 A. Osman El-Tom, "Berti Qur'anic Amulets," Journal of Religion in Africa 17, no. 3 (1987): 243. wanted to write that gave those words their intended efficacy.

The following kirsh kitab examples draw these themes together. Each text was produced by a different sa'ig, but each text was etched with the aim of replicating the "Aya al Kursi" to fend off Umm al Subyan, thereby making textual conformity a probable outcome. This is not the case here. The imprecisions of the manuscript art, any faults of mnemonic control, and the limitations of pre1970s education in inner Oman, ${ }^{71}$ when the available maktab or kuttab (Qur'ān-based primary school) literacy could denote some Qur'ānic reading and memorization ${ }^{72}$ without the ability to write, ${ }^{73}$ are all liable for the textual variations that appear across kirsh kitab samples. Before looking at the words written by the suwwag, the complete "Aya al Kursi" is given for comparison since it is the archetypical text:

Allah, there is no god but $\mathrm{He}$

The Living, the Eternal, He cannot be taken by slumber nor sleep,

His are all things in the heavens and on earth.

Who is there that can intercede in His presence except as He permits?

He knows what is

Before or behind them,

Nor shall they compass aught of His knowledge except as He wills it.

His Throne extends over the heavens and the earth, And He feels no fatigue in preserving them And He is the Most High, the Supreme. ${ }^{74}$

71 Limbert, In the Time of Oil, 5 and 86, respectively.

72 Said, interviewed by the author, Nizwa, Oman, March 16, 2018.

73 Konrad Hirschler, The Written Word in the Medieval Arabic Lands: A Social and Cultural History of Reading Practices (Edinburgh:Edinburgh University Press, 2011), 16. 'Abdullah Yusuf 'Ali, The Meaning of the Holy Qur'ān (Beltsville, MD: Amana Publications, 2001), 105-06. This translation by 'Ali has been amended and adapted by the author. 
The next three texts are from kirsh kitab and are offered, line by line, exactly as they have been carved into the silver. With the original Arabic text, misspelled words are provided in green but spelled as they were written, words missing from a line are marked with an ellipsis in parenthesis, broken words are indicated with a hyphen where the split occurs, and added words are written in red. The English translations are notated the same except for misspelled words. If a word from "Aya al Kursi" is misspelled, but it is still an actual word, the resulting translation is green; if the misspelled word is not a word, but it is identifiable as part of "Aya al Kursi," then what is assumed to be the intended translation is green and placed in brackets.

Text $\mathbf{1}^{75}$

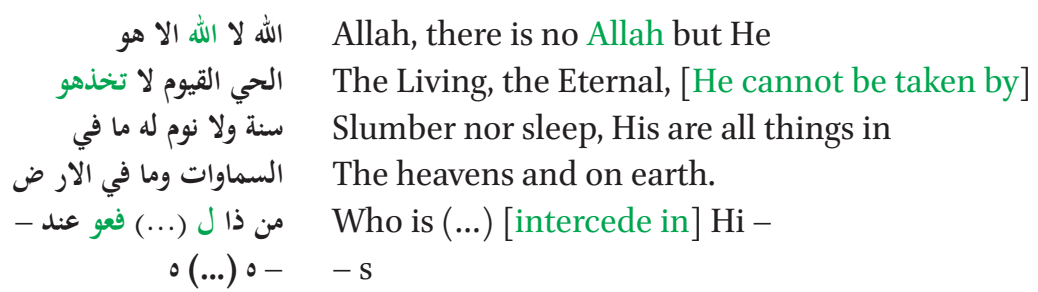

Text $2^{76}$

\begin{tabular}{|c|c|}
\hline الله لا اله الا هو & Allah, there is no god but $\mathrm{He}$ \\
\hline حي القيوم لا تاخذه سنة & $\begin{array}{l}\text { Living, the Eternal, He cannot be taken by } \\
\text { slumber }\end{array}$ \\
\hline ولا نوم له ما في سماوات وما في ار - & Nor sleep, His are all things in heavens and on ear- \\
\hline من ذا الذي يشفع عنده الا با- & $\begin{array}{l}\text { - th. Who is there that can intercede in His } \\
\text { presence except as He per - }\end{array}$ \\
\hline يعلم ما بين ايديهم وما خل - & - mits? He knows what is before or [be - \\
\hline 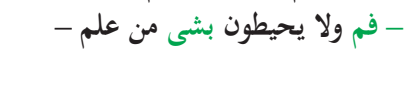 & $\begin{array}{l}\text { - hind them], nor shall they compass aught of His } \\
\text { know - }\end{array}$ \\
\hline ك- ك ك الا بما شاء وسع & $\begin{array}{l}\text { - ledge except as He wills it. Extends } \\
\text { His Throne }\end{array}$ \\
\hline
\end{tabular}

Text $3^{77}$

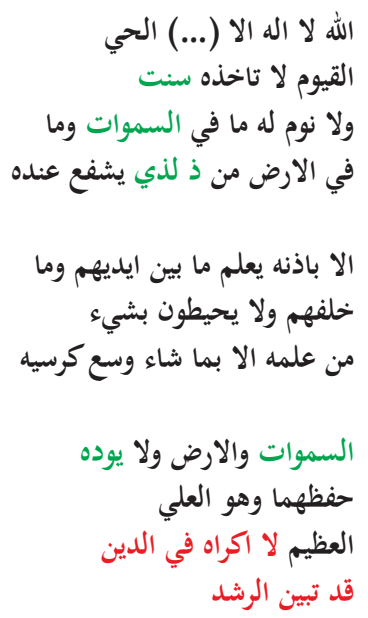

Allah, there is no god but (...) the Living, The Eternal, He cannot be taken by [slumber] Nor sleep, His are all things in [the heavens] and On earth. Who [is there that can] intercede in His presence

Except as He permits? He knows what is before or Behind them, nor shall they compass aught Of His knowledge except as He wills it. His Throne extends over

[The heavens] and the earth, and He does not like Preserving them and He is the Most High, The Supreme. There is no compulsion in religion The truth stands out ${ }^{78}$ 
The omissions andlapses shownin the kirsh kitab texts above are not outliers; of the more than one hundred kirsh kitab texts that were examined, there was hardly a single one that could pass as an impeccable reproduction of "Aya al Kursi." The factors that are likely at the root of these errors have already been presented. What remains to discover is why such flagrant textual flaws were passable.

\section{Mnemonic Alchemy and the Logic of Textual Imperfection}

At first, it might seem barely conceivable that any of the hallowed words from the Qur'an could become as mangled as they were, as texts one through three show, and yet still be sought as a deterrent against a jinniya as horrific and devastating as Umm al Subyan. ${ }^{79}$ Naturally, the thought occurs that it cannot be too out of the ordinary that, when unlettered men engraved texts for unlettered women, ${ }^{80}$ some inaccuracies were bound to happen. Besides, there is also plenty of data compiled from other settings that demonstrate the weight that written words carry, especially holy words, among those who cannot read well. This is apparent in the research of Mercedes García-Arenal about written Arabic for Moriscos in Spain: "The

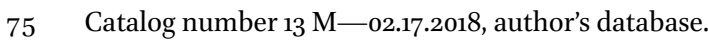

76 Catalog number $4 \mathrm{~N}-\mathbf{0 4 . 2 0 . 2 0 1 8}$, author's database.

77 Catalog number $17 \mathrm{~N}-03.16 .2018$, author's database.

78 These additional words are from the first line of the aya that follows "Aya al Kursi."

79 Even now, many Omanis insist that the kirsh kitab are faithful renderings of the "Aya al Kursi" and that any mistakes with the words were due to the inexperience of novice craftsmen. Unless every piece currently available for purchase was made by a trainee, then what this position really suggests is that Omanis today find it implausible that these silver texts with their divine contents could be so contorted.

8o There is no shortage of data about the dearth of literacy and educational facilities in premodern inner Oman. For a good description, see Rabi, The Emergence of States, $49^{-52}, 155^{-5} 8$, and 208 . women in this case, as in many others, were illiterate. The function of the written word was not dependent on its being read and understood but was related to the power which the believer assigned to that writing. In other words, the word did not necessarily form part of an act of communication but took on a magical or talismanic character, and was used as such." ${ }^{81}$ García-Arenal's portrayal of a relationship with texts by those who could not read them is close to that which the kirsh kitab shared with their owners, that is, the faith that the unknown characters were protective no matter how they might have been arranged or fractured because they were believed by the unlettered to represent the words of the scriptures (fig. 10.3).

Where did that trust in the efficacy of the sometimes jumbled kirsh kitab texts stem from? It did not come from ignorance of the printed word even though that was an unavoidable component. What seems to have been filling in for literacy when purchasing these texts was a buyer's confidence in a maker's intentions. Abdellah Hammoudi calls discrepancies in ritual practice "the gap ... between effort and achievement" and reminds us that there are always divides "between what is said and what could possibly be meant." 82 Likewise, the faults on the kirsh kitab can be said to reflect a split between mnemonic control and textual expression, though intent (niyah) could reconcile those breaches. If a sa'ig memorized the "Aya al Kursi" or whatever other aya was required and applied it to a silver medallion with the intent of making it for the

81 Mercedes García-Arenal, "The Converted Muslims of Spain: Morisco Cultural Resistance and Engagement with Islamic Knowledge (1502-1610)," in Routledge Handbook of Islam in the West, ed. Roberto Tottoli (New York: Routledge, 2015), 51.

82 Abdellah Hammoudi, "Textualism and Anthropology: On the Ethnographic Encounter, or an Experience in the Hajj," in Being There: The Fieldwork Encounter and the Making of Truth, ed. John Borneman and Abdellah Hammoudi (Berkeley: University of California Press, 2009), 28. 


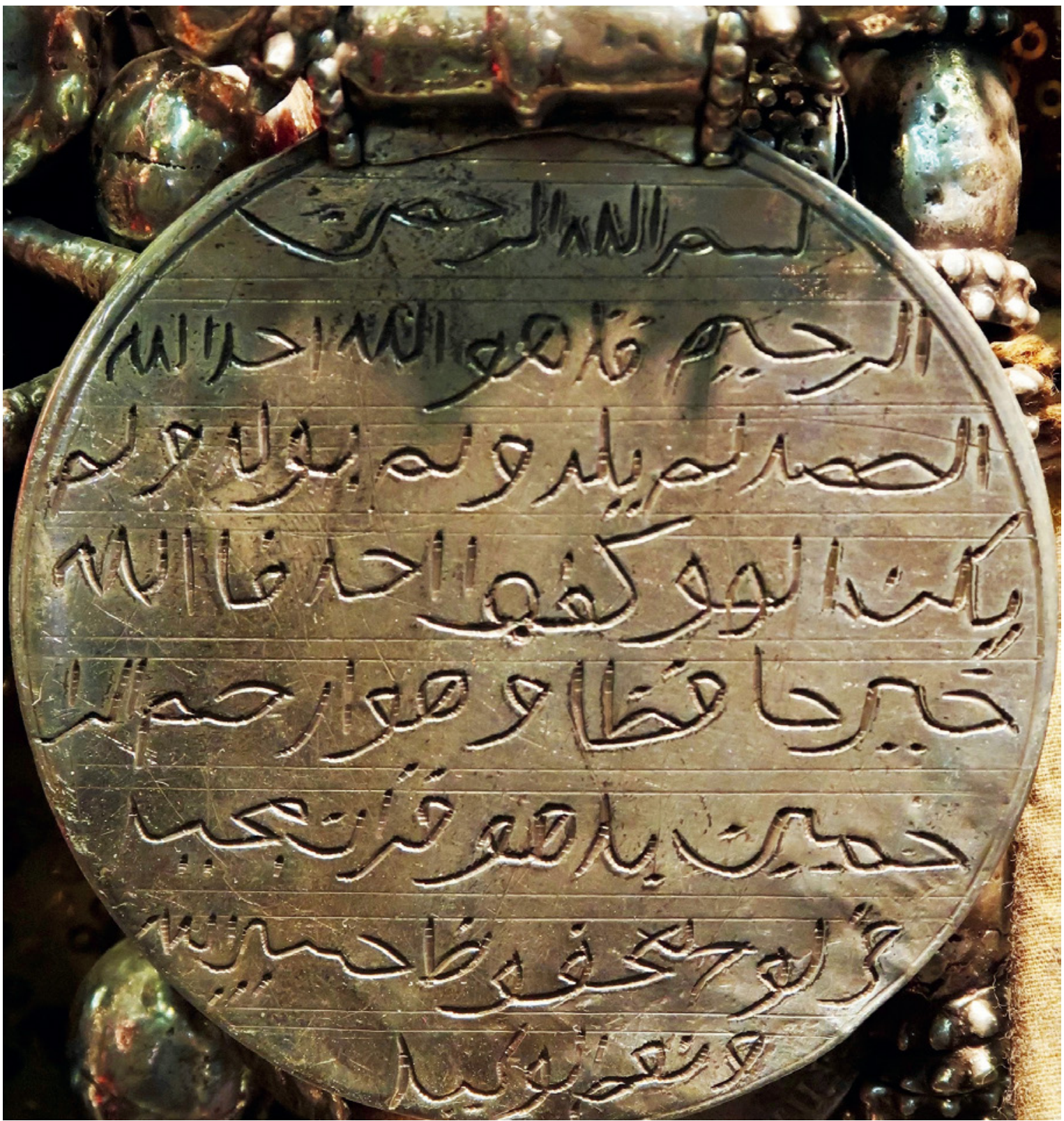

FIGURE 10.3 The eclectic blending of writing on this kirsh kitab shows both the variability and the partial texts that can be found on different samples. It features no words from "Aya al Kursi"; instead, Surat al Ikhlas (The Sincerity Chapter) 112:1-4 and Surat al Buruj (The Constellations Chapter) 85:2 are complete, but only fragments of Surat Yusuf (Yusuf Chapter) 12:64 and Surat al Imran (The Family of Imran Chapter) 5:173 are present.

select purpose of protecting its wearer, without other thoughts of money or profit or anything else, the resulting kirsh kitab could be expected to perform as planned. All that was left for customers was to know how to gauge a silversmith's intent, and this relied heavily on a sa'ig's reputation for religious piety and practice, with elements like prayer and alms-giving being part of this equation. 83

83 Salim, interviewed by the author, Nizwa, Oman, November 4, 2017. 
Finally, nearly all kirsh kitab display a tied-up likeness of Umm al Subyan, the feared jinniya whose wrath should be disabled by the presence of the partial holy texts, engraved into their surfaces. ${ }^{84}$ As an "iconographic symbol" 85 that made the target and desired effect of the scriptures unmistakable, even to the completely unlettered for whom a written aya was no more than a collection of lines with curves and dots, ${ }^{86}$ the graphic depiction of Umm al Subyan was a recognizable affirmation of a sa'ig's talents and a literal representation of the words on the kirsh kitab that would render the jinniya harmless. In the recollections of one elderly sa'ig renowned for his silver writing who used to write on occasion for less gifted suwwag, the image of the jinniya as it appeared on a disc had to come from within the maker; it had to come from his heart. ${ }^{87}$ Only then, by drawing into silver what he saw inside himself, could the sa'ig display Umm al Subyan as being neutralized by the words around her.

\section{Conclusion: The Good Judge's Memory}

It is difficult to contemplate the roles of mnemonic authority in the fabrication of imperfect texts and their reinforcing graphics without recalling some of the age-old questions about the very nature of memory and writing. Jacques Derrida explored Plato's arguments about the association between the two when he wrote of writing as having "no essence or value of its own ... It is in its type the mime of memory, of knowledge, of truth, etc." ${ }^{8}$ This distillation of the ancient orator's take on texts that "the best of them really serve only to

\footnotetext{
84 Only 18 of 116 documented kirsh kitab are without a jinniya image.

85 Ong, Orality and Literacy, 74.

86 Grehan, Twilight of the Saints, 153.

87 A sa'ig interviewed by the author, Nizwa, Oman, May 11, 2018.

88 Jacques Derrida, Dissemination, trans. Barbara Johnson (Chicago: University of Chicago Press, 1981), 105.
}

remind us of what we know"89 actually might encompass some of the logic of coin writing in that the silver texts were ultimately mnemonic products whose effectiveness seems to have rested more on a sa'ig's memory than on exact textual reproduction.

Taking Derrida's inquiry into Plato's contentions further is even more revealing because it goes past the postulation that memory and texts are somehow inimical to each other. Turning to Laws, XII: 957-58, Derrida brings attention to Plato's insistence that texts and their memorization are the cornerstones of the "good judge."90 In Plato's phrasing, "of all such speeches, the writings of the lawgiver will serve as a test; and inasmuch as he possesses these within himself, as a talisman against other speeches, the good judge will guide both himself and the State aright." 91 Here, little licence is required to make the transference from the good judge to the sa'ig, from the texts of the lawgiver to the divine Scripture by Allah, or to see that the talismanic shelter created by internalizing these writings can equally apply to magistrate and silversmith so that each might better tend his State or clientele.

The texts on the silver discs that were churned out of workshops in inner Oman complicate perceptions about writing, texts, and memory, and not just because Derrida and Plato can intermittently cloud things with contradictions. This confusion arises because the suwwag's writings were taken from a sacred source that is at once textual and mnemonic, scriptural and recitational, ${ }^{92}$ and thus resists placement into binary categories that are one or the other. ${ }^{93}$ At the same time, all the

89 Harold North Fowler, Plato with an English Translation, Volume 1, Euthyphro, Apology, Crito, Phaedo, Phaedrus (Cambridge, MA: Harvard University Press, 1943), 573. Derrida, Dissemination, 121. R.G. Bury, Plato with an English Translation: Laws (London: William Heinemann, 1926), 2: 527. William A. Graham, "The Earliest Meaning of 'Qur'ān," Die Welt des Islam 23/24 (1984): 372. 
protective inscriptions made by craftsmen to keep Umm al Subyan at bay were ancillary to the ups and downs of the Omani silver market. A sa'ig was a writer of memorized texts that gave people safety, but his scribal services were needed only as long as local silver prices remained buoyant; when people stopped buying silver, they also stopped buying his texts and, by extension, the amuletic properties of his memory. The lot of the wretched jinniya, now that Oman's silver era and its kirsh kitab has ended, curiously remains unsure. 